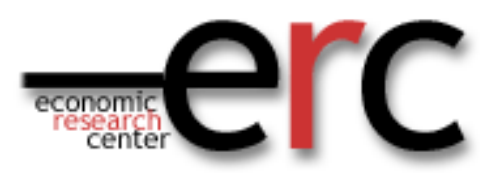

ERC Working Papers in Economics 13/05

May/ 2013

\title{
Output-Employment Relationship across Sectors: A Long- versus Short-Run Perspective
}

\author{
Afşin Şahin \\ Department of Banking \\ School of Banking and Insurance \\ Gazi University \\ 06571 Ankara \\ Turkey \\ Phone: ++90 3125821065 \\ Fax: ++ 903125821145 \\ e-mail: afsinsahin@gazi.edu.tr \\ URL: http://websitem.gazi.edu.tr/afsinsahin
}

\author{
Aysit Tansel \\ Cornell University, Ithaca, NY USA \\ \& \\ Department of Economics \\ Middle East Technical University \\ 06531 Ankara, Turkey \\ $\&$ \\ Institute for the Study of Labor (IZA) \\ Bonn, Germany \\ \& \\ Economic Research Forum (ERF) \\ Cairo, Egypt. \\ Phone: ++90 3122102057 \\ Fax: ++90 3122107964 \\ e-mail: atansel@metu.edu.tr \\ M. Hakan Berument \\ Department of Economics \\ Bilkent University \\ 06800 Ankara, Turkey \\ Phone: ++90 3122902342 \\ Fax: ++90 3122665140 \\ e-mail: berument@bilkent.edu.tr \\ URL: http://www.bilkent.edu.tr/ berument
}




\title{
Output-Employment Relationship across Sectors: A Long- versus Short-Run Perspective
}

\author{
Afşin Şahin * \\ Department of Banking \\ School of Banking and Insurance \\ Gazi University \\ 06571 Ankara \\ Turkey \\ Phone: ++90 3125821065 \\ Fax: ++ 903125821145 \\ e-mail: afsinsahin@gazi.edu.tr \\ URL: http://websitem.gazi.edu.tr/afsinsahin \\ Aysit Tansel \\ Cornell University, Ithaca, NY USA \\ \& \\ Department of Economics \\ Middle East Technical University \\ 06531 Ankara, Turkey \\ $\&$ \\ Institute for the Study of Labor (IZA) \\ Bonn, Germany \\ $\&$ \\ Economic Research Forum (ERF) \\ Cairo, Egypt. \\ Phone: ++90 3122102057 \\ Fax: ++90 3122107964 \\ e-mail: atansel@metu.edu.tr \\ M. Hakan Berument \\ Department of Economics \\ Bilkent University \\ 06800 Ankara, Turkey \\ Phone: ++90 3122902342 \\ Fax: ++90 3122665140 \\ e-mail: berument@bilkent.edu.tr \\ URL: http://www.bilkent.edu.tr/ berument
}

\footnotetext{
* Corresponding author: Afşin Şahin, Department of Banking, School of Banking and Insurance, Gazi University, 06571, Ankara, Turkey. We would like to thank Yılmaz Akdi and Hasan Türe for their valuable suggestions.
} 


\title{
Output-Employment Relationship across Sectors: A Long- versus Short-Run Perspective
}

\begin{abstract}
This paper investigates the nature of the output-employment relationship by using the Turkish quarterly data for the period from 1988 to 2008. Even if we fail to find a long-run relationship between aggregate output and total employment, there are long-run relationships for the aggregate output with non-agricultural employment and sectoral employment levels for seven of nine sectors that we consider. However, a further investigation for the output and employment relationship within a short-run perspective do not reveal statistically significant relationships for either total employment, or non-agriculture employment or the eight out of the nine sectors that we consider. Thus, it seems that sustainable growth is an essential economic agenda for employment generation concerning the sectors and that there is a longrun link but weak short run link with demand.
\end{abstract}

JEL codes: C32, E24 and E32.

Key words: Output; Employment; Seasonal Cointegration. 


\section{Introduction}

Unemployment constitutes a large component of the cost of business cycles. Thus understanding the dynamics of unemployment and its relation to the overall economic performance is vital. "Jobless growth" is one of the features of the recent global financial crisis in the world. It seems recovery in output does not bring higher employment or lower unemployment (see for example, Bernanke, 2003, Groshen and Potter, 2003 and Khemraj, Madrick and Semmler, 2006 for the US and Bent, 1991, Fox and Sekkel, 2006, Verme, 2006, World Bank, 2007 and 2008, Nabli, Jauregi, Carlos, Silva, 2007, for developing countries). This paper provides evidence on the relationship between employment and output from Turkey by imposing long-run versus short-run distinction on this relationship using quarterly data from 1988 to 2008.

Turkey is an important predominant emerging market with small-open economy features and relatively well developed markets. Turkey ranked as the 17th largest economy in the world in terms of its GDP as of 2009 (PWC, 2010, p. 3). Thus, it is a relevant case study for other emerging economies. Moreover, Turkey provides a unique laboratory environment to assess any relationship between output and employment. First, Turkey has high output and employment volatilities ${ }^{1}$ therefore probability of committing a type II error (not rejecting the null when it is not true) will be lower. In other words, any relationship between output and employment will be easier to detect. Second, even if Turkey has relatively tight formal labor market; its high population growth, high real wage flexibility thanks to high inflation ${ }^{2}$, high informal labor market share earning less than the formal workers (see Baltagi, et al., 2012, p. 2), and its high internal migration make its labor market flexible. Thus, assessing the relationship between output and employment is meaningful in such a flexible labor market. Moreover, Turkey is an important emerging economy and any conclusion drawn from this study can be valuable for other emerging economies.

The relationship between employment and output may differ depending on the framework considered. Morrison and Berndt (1981) and the references cited therein argue that

\footnotetext{
${ }^{1}$ The mean and standard deviation of real GDP growth between $1989-2008$ is Egypt $(4.6 \% ; 1.58)$, Greece $(2.90 \% ; 1.83)$, Italy $(1.40 \% ; 1.25)$, Jordan $(4.79 \% ; 5.74)$, Peru $(3.56 \% ; 5.55)$, Portugal $(2.40 \% ; 2.19)$, Syria $(4.43 \% ; 4.53)$ and Turkey $(4.12 \% ; 4.67)$ respectively according to USDA database. The total unemployment rate (\% of total labor force) and its standard deviation for this period is Egypt $(9.51 \% ; 1.22)$, Greece $(9.27 \% ; 1.31)$, Italy $(9.73 \% ; 1.89)$, Jordan $(14.84 \% ; 2.28)$, Peru $(8.47 \% ; 1.48)$, Portugal $(5.91 \% ; 1.44)$, Syria $(8.64 \% ; 3.12)$ and Turkey $(8.76 \% ; 1.51)$ according to World Development Indicators data.

2 Turkey is the only country that had a high inflation without running into hyperinflation. The mean and standard deviation of the annual inflation for our sample period was $54.26 \%$ and 30.22 compared to Egypt $(9.87 \% ; 6.33)$, Greece $(8.04 \% ; 5.92)$, Italy $(3.54 \% ; 1.64)$, Jordan $(5.82 \% ; 6.12)$, Peru $(579.42 \% ; 1747.82)$, Portugal $(5.17 \% ; 3.66)$ and Syria $(8.27 \% ; 8.71)$ according to the World Development Indicators, Consumer Price Index $(2005=100)$.
} 
the short-run output elasticity of demand is smaller than unity and is less than that of the longrun. There might be various reasons for this. First, higher aggregate demand may encourage firms to increase their production but, this increase may not lead to higher number of people worked (employment). It may only lead to an increase in the number of hours worked for each worker. This might be due to the fact that new workers need to be trained and oriented before engaging in production, and during the learning process the productivity of workers may likely to be lower. Therefore, firms may rely on the overtime work rather than to increase employment in the short-run. Once this increase in aggregate demand is perceived permanent, then the firms may increase the number of workers in order to increase production and bear the cost of new employment. Conversely, firms may not lay off workers as the aggregate demand decreases because decreasing employment may be costly due to firing costs as the economy falls into a slump. Firms may decrease over time work, but not decrease number of workers if the aggregate demand decrease is perceived temporary, but they may decrease employment if the decrease in aggregate demand is perceived permanent.

Second, the effects of the shocks to the labor market may die out later than the effects of the shocks to the output in the short-run because of the rigidities in the labor market. The elimination of the difference between actual and long-run employment rate may take more time than the elimination of the output gap as mentioned in Layard, Nickell and Jackman (1991, p. 77). Labor market movements are smaller than the movements in the goods market and the changes in output are accompanied by smaller changes in employment. Therefore, the problem of creating employment may be structural in the economy and the employment generation ability of the supply side of the economy may be weaker in the short-run. However, in the long-run, goods and labor markets nearly clear with long-memory and an interaction emerges between two markets. ${ }^{3}$

On the other hand, a possible relation between employment and output may not be the same across different sectors of the economic activity. Sawtelle (2007) argues that the employment elasticities among five sectors that she considers for the US economy are different. Berman and Pfleeger (1997), Echevarria (1997), Bhalotra (1998), Bhorat and Hodge (1999), Goodman (2001), Dasgupta and Singh (2005), Tregenna (2008) also argue that the employment generation in response to the aggregate supply shocks across the sectors of the economy might be different. The reason for this can be the cyclical behavior of the sectors,

\footnotetext{
${ }^{3}$ Wilson (1960) and Brechling (1965) elaborate similar issues as early as 1960s.
} 
deregulation of the industry and trade, purchasing postpones of the firms, different wages, productivity differences, different employment multipliers, different labor or technological intensities and inter-sectoral outsourcing of each sector.

The purpose of this paper is two-folds. The paper first examines the possible relationship between output and employment for the whole economy and next considers the employment in each sector and total output to assess the employment creation capacity of each sector to changes in total output. Two different time frames are used in carrying out this analysis: short-run versus long-run. In this analysis, we could use employment and the corresponding output in each sector. Unfortunately, output in each sector that matches the employment definition is not available for the country that we study - Turkey. However, using the employment in each sector in relation to the total output allows us to assess an important question regarding how the total employment and the sectoral employments react to the changes in aggregate demand.

There are several studies that investigate the possible relationship between output and employment (or unemployment). One of the earliest studies that investigate the relationship between output and employment disaggregated by sector is by Madden and Tuckewell (1975). They consider various sectors in the Australian industry and claim that in most of these sectors, the short-run fluctuations in sectoral and total output have no relation to the fluctuations in sectoral and aggregate employment. Wah (1997) investigates the employment effects of output and technological progress in the Malaysian manufacturing sector. He claims that the domestic demand and export expansion improve the total industrial employment creation. Lewis-Wren (1986) investigates the effect of expected output on UK manufacturing employment and finds significantly positive effect of output expectations on employment. Smyth (1986) studies the cyclical effects of output changes on manufacturing employment in the US. He differentiates between the employment of production and non-production workers and finds that his adjustment speed model works for production worker where the cost of increasing employment is higher if unemployment rate is lower. Pehkonen (2000) investigates the effect of cyclical total output growth on total employment and unemployment in Finland and observes a stable relation. According to his study, the effect of the changes in the rate of total output growth on total employment takes a considerable lag.

There are several papers analyzing the effect of output on employment in Turkey. For instance, Akçoraoğlu (2010) investigate the long-run relationship between employment and the real GDP using Johansen cointegration and Engle-Granger cointegration methods. The dynamic error correction model, he employs results in a short-run relationship with lagging 
negative effect of real GDP on employment. He also finds bi-causality between real GDP and employment. Aydıner-Avşar and Onaran (2010) find a positive long-run effect of total manufacturing industry output on employment in Turkey. It is interesting that this effect is lower for the high and medium skilled workers compared to low skilled workers. Akan, Arslan, Karatay and Druica (2008) benefit from the causality analysis and claim that the economic growth does not affect the employment rate in Turkey. However, they do not reject the reverse hypothesis. Tatoğlu (2011) finds a long-run and short-run relationship between unemployment and output which varies among the countries including Turkey. There are also papers emphasizing the issue of jobless growth and the low employment creation capacity of the Turkish economy such as Telli et al. (2006) and Yeldan (2010). Some of the papers consider the asymmetric relationship between output and the employment market. Tiryaki and Özkan (2011) and Tarı and Abasız (2010) investigate the asymmetric case for the Okun's law for Turkey. The sectoral analysis of employment for the Turkish economy was also considered by several authors. Berument, Dogan and Tansel (2008) claim that the responses of the sectoral unemployment rates are not the same and they depend on the type of shocks. Günçavd1, Küçükçiftçi and Mckay (2004) using input-output tables show that the openness in trade of the intermediate goods creates a demand for the workers in Turkish economy.

The main contribution of this paper is analyzing the possible relationship between employment and output by distinguishing its long-run versus short-run nature. The possible relationship is investigated by employing seasonal integration, cointegration and errorcorrection models. We initially consider the relationship between output and unemployment as inspired by the works of Okun $(1962,1970)$. Okun's law postulates that the fall of about three percent in the growth rate of real gross national product leads to one percent increase in the unemployment rate. This specifies the cost of unemployment in terms of output. This proposition is empirically verified by several studies such as by Hamada and Kurosaka (1984) in Japan, Kaufman (1988) in the US, Canada, Japan, UK, Sweden, and Germany, Blanchard (1989), Prachowny (1993), Weber (1997), Freeman (2000), Cuaresma (2003), Holmes and Silverstone (2006) in the US, Moosa (1997) in G7 countries, Attfield and Silverstone (1998) in UK, Sögner (2001) in Austria, Sögner and Stiassny (2002) in 15 OECD countries and Villaverde and Maza (2009) in Spain.

In our investigation we failed to find a statistically significant relationship between output and unemployment in Turkey ${ }^{4}$. We believe that this failure is due to the nature of the

\footnotetext{
${ }^{4}$ The level of significance is at the $5 \%$ unless otherwise stated.
} 
data used on which we elaborate in the data section. We then switched to specifying a model whereby the activities in the labor market as measured by the employment rate is related to the activities in the goods market as measured by the aggregate output. A number of authors such as Akerlof and Shiller (2009, p.2) point out that when evaluating the labor market, it may be more meaningful to use the employment rates rather than the unemployment rates. Similarly, in the case of Turkey, it is argued that the unemployment rate and the employment rate are not the mirror images of each other as indicators of the labor market conditions. Employment rate may better reflect the slack or the boom in the labor market than the unemployment rate in Turkey (World Bank, 2006, p. 13). Accordingly, we focus on the employment rate rather than the unemployment rate in the analysis in this paper. We first investigate the effect of an increase the aggregate output on the aggregate employment rate. Next, we investigate the effect of the same increase on the employment rates in the various sectors of economic activity.

The focus of this paper is a twenty year period of economic expansion in the Turkish economy although with periods of volatility. During the period of study from 1988 to 2008 the real GDP increased by 4 percent while the total employment grew by 1 percent annually. There had been several major economic and financial shocks since the year 1988. The first negative shock to the economy occurred in 1991 and was due to the Gulf War. The second crisis occurred in 1994 when GDP dropped by about 6 percent along with a devaluation of the Turkish Lira by 70 percent against the US dollar. The third crisis occurred in 1999 and was due to both the two major earthquakes in the industrial heartland of the country and the aftermath of the Russian crisis. The fourth crisis occurred during 2000-2001. The per capita GDP declined by 9.6 percent in 2001 but recovered quickly with an 8 percent increase in 2002 and with subsequent high growth rates. However, the unemployment increased during the last crisis and remained high in spite of the subsequent high rates of output growth. This is referred to as "jobless growth" phenomenon. Finally, the Turkish economy is affected by the global economic crisis. The effect of the global crisis was felt starting in the second quarter of 2008. The GDP growth rate declined to $2.6 \%$ and to $0.9 \%$ in the second and third quarters of 2008 respectively. The GDP declined by $7 \%$ in the last quarter of 2008 . The annual growth rate averaged to only $0.7 \%$ in 2008 . The effect of the global crisis was most severe in 2009 when GDP declined by $4.7 \%$. The economy recovered in 2010 with growth rates reaching to about 10-11 percent in the first two quarters of 2010. The total and non-agricultural unemployment rates were very high in 2009 but returned to the pre-crisis levels in 2010. Recently the topic of jobless growth has been an important concern in the US (Bailey and 
Lawrence, 2004) and other developed countries. In this paper, we also provide an insight to the "jobless growth" phenomenon experienced in the Turkish economy by examining the responsiveness of the aggregate and sectoral employment to aggregate demand as proxied by aggregate output.

There are some surprising, as well as expected, interesting results in this paper. First of all, we fail to find a long-run relationship between aggregate output and total employment. The long-run relationship exists for the aggregate output and non-agricultural employment and for the aggregate output and sectoral employment levels for seven of the nine sectors that we consider. Second, a further investigation of the aggregate output and employment within a short-run perspective reveals the following. There is no statistically significant short run relationship between aggregate output on the one hand and total employment on the other. Further, aggregate output is not related to the non-agricultural employment and to the eight out of the nine sectoral employments that we consider. Our results provide an insight to the "jobless growth" phenomenon. Agriculture and construction are the two sectors that do not show a neither long run or a short run relationship to total output, displaying the "jobless growth" characteristics. Further, we find statistically significant short-run relationships only for the wholesale and retail trade sectors. Therefore, all but the wholesale and retail trade sectors exhibit "jobless-growth" characteristics in the short-run.

This paper is structured and laid out as follows. Section 2 introduces the data utilized in this paper and notes their sources. The methodology employed in the analysis is presented in Section 3. Section 4 presents and discusses the estimation results. Concluding remarks appear in Section 5.

\section{Data}

The data used in this study are taken from the Central Bank Republic of Turkey (CBRT) electronic data delivery system (EDDS). It is quarterly data pertaining to the period 1988Q4 -2008Q4. Using the quarterly data has two advantages. First, the quarterly data rather than the monthly data increases the probability of indicating a relation between output and employment as indicated, for example, by Wilson (1960) because "the shorter the run, the less stable is the output-employment relationship." So the short-run is marked by the adjustment processes and extracting the signal from the quarterly data may be easier. Second, by using the quarterly data rather than the annual, it is possible to increase the number of observations and we may detect richer array of integration with quarterly data when we use the seasonal cointegration method. Real Gross Domestic Product (GDP) is used as a measure of output. It 
is measured in terms of Turkish Liras (TL) in 1987 prices and computed by using the expenditure approach. After 2007Q4 there was a change in the methodology of computation of GDP. For the period after this date we imputed the data by taking quarterly percentage changes in order to preserve conformity with the data of the previous period.

Employment data is also taken from the Electronic Data Delivery System (EDDS) of the CBRT. Turkish Statistical Institute (TurkStat) had published labor market data based on Household Labor Force Surveys which had been conducted semiannually during the years from 1988 to 1999 . The employment data consists of the number of people rather than the number of working hours. After 2000 these surveys are conducted quarterly. We transformed the semiannual data of the pre-2000 period to the quarterly data by using the methodology of Chow and Lin (1971) in order to use the quarterly data for the entire period of analysis. Same methodology is applied both to the total employment data and to the employment data disaggregated by the sectors of main economic activity. The nine sectors of economic activity considered in this paper are listed and described in Appendix Table A1. All variables are used in their logarithms in the analyses.

\section{Methodology}

We first analyze the possibility of seasonal integration following Hylleberg, Engle, Granger and Yoo (HEGY, 1990) and Hamori and Tokihisa (2001) which is applicable to quarterly data. $^{5}$

Assume that the string $\left\{x_{t}\right\}, t=1,2, \ldots, T$, is transformed into four parts for capturing seasonal behavior of the data ${ }^{6}$. Therefore equations (1) through (4) are the observed series adjusted for the seasonal unit roots at $\theta=0, \pi,(\pi / 2$ and $3 \pi / 2)$ frequencies where $B$ is defined as a lag operator ${ }^{7}$ :

$$
x_{1, t}=(1+B)\left(1+B^{2}\right) x_{t}=\left(1+B+B^{2}+B^{3}\right) x_{t}
$$

The second string is observed series adjusted for the unit roots at $\theta=0, \pi / 2, \pi, 3 \pi / 2$ :

$$
x_{2, t}=-(1-B)\left(1+B^{2}\right) x_{t}=-\left(1-B+B^{2}-B^{3}\right) x_{t}
$$

\footnotetext{
${ }^{5}$ In this paper we investigate both the short and the long-run dynamics. The Engle-Granger cointegration methodology allows us to do so. However, the Johansen multi-equation cointegration methodology uses the rank of the matrices to judge for a long-run relationship and does not permit us to observe any uniquely identified short run dynamics within a multi-equation framework.

${ }^{6}$ Hylleberg, Engle, Granger and Yoo (1990) claim that when the economic data contain substantial seasonality then there is a high possibility that there can be unit roots at other frequencies such as the seasons besides the annual frequency.

${ }^{7}$ Note that, $\pi$ refers to the six-month-cycle when we consider it with a unit circle.
} 
The third string is observed series adjusted for the unit roots at $\theta=0, \pi$ :

$$
x_{3, t}=-\left(1-B^{2}\right) x_{t}
$$

And the fourth one is defined by the equation (4):

$$
x_{4, t}=-\left(1-B^{4}\right) x_{t}
$$

An auxiliary regression is utilized to the effects of first three series on the fourth sequence so we estimate the equation (5) to obtain HEGY unit root statistics for different frequencies:

$$
x_{4, t}=C+\Lambda_{1} x_{1, t-1}+\Lambda_{2} x_{2, t-1}+\Lambda_{3} x_{3, t-1}+\Lambda_{4} x_{3, t-2}+\sum_{i=1}^{p} \phi_{i} x_{4, t-i}+e_{t}
$$

Deterministic parts of the equation (5) are expressed by the parameter $C$ which has four possible differentiated cases: \{Intercept $(I)\},\{$ Intercept $(I)$, Seasonal Dummies $(S D)\}$, $\{$ Intercept $(I)$, Trend $(\operatorname{Tr})\}$, \{Intercept $(I)$, Seasonal Dummies $(S D)$, Trend $(T r)\}$. The significances of the parameters $\Lambda_{1}$ through $\Lambda_{4}$ are tested by the $t$ - and $F$ - statistics. If the Ordinary Least Square (OLS) estimate results for $\Lambda_{1}$ is equal to zero, then we may claim that there is a non-seasonal unit root. If $\Lambda_{2}$ is equal to zero then there is one seasonal unit root. If the last two parameters are both equal to zero, which is tested by $F$-statistics, we then claim that there is a conjugate pair of complex unit roots.

\section{Empirical Evidence}

\section{IV.a. Aggregate Employment and Output}

The unit root tests for the aggregate output and total employment variables in their logarithms are performed and the test statistics are reported in Table 1. Since the production and employment in the agricultural sector depend on various periodic elements and shocks such as rain fall, weather conditions, yield levels and government supports (see, for example, Şahin, Akdi and Arslan, 2007, Şahin, 2008, Dudu and Çakmak, 2011), we also report the results with non-agricultural employment by excluding the agricultural employment. The auxiliary regressions are run with (a) an intercept term, (b) an intercept term and seasonal dummies (c) an intercept term and a time trend (d) an intercept term, seasonal dummies and a time trend. We considered lag orders of four, six and eight in equation (5) for the robustness of our test results. The table suggests that all three series have unit roots at zero frequency. The unit roots can be rejected in the output series at $\pi, \pi / 2$ and $3 \pi / 2$ frequencies, and in 
the non-agricultural employment series at $\pi$ frequency. However, the aggregate employment series has a unit root at all the frequencies that we consider.

< Insert Table 1 here>

Next, we carried out the residual based cointegration test developed by Engle, Granger, Hylleberg and Lee (1993). For the zero frequency case equation (6) is estimated:

$$
\left(1+B+B^{2}+B^{3}\right) \text { employment } t_{t}=C+\beta_{1}\left[\left(1+B+B^{2}+B^{3}\right) y_{t}\right]+u_{t}
$$

$C$ is the deterministic part of the equation consisting of constant, three seasonal dummies and the intercept dummy for 2005:01-2008:4. We include the intercept dummy in order to account for the change in the calculation method of GDP in 2005. Here, we specified the same deterministic term for all types of cointegrating regressions. $u_{t}$ is the residual of the cointegrating equation. Equation (7) is the auxiliary regression of $\Delta u_{t}$ on its lagged values:

$$
\Delta u_{t}=\tau_{1} u_{t-1}+\sum_{i=1}^{\rho} \psi_{i} \Delta u_{t-i}+\varepsilon_{1, t}
$$

We utilized four lags in the equation (7). Similar to the Augmented Dickey Fuller unit root test, we make inference on the estimated coefficient of $u_{t-1}$. If we reject the null of unit root, we claim that in the long-run, there is a cointegration between output and employment. The critical values of the coefficient for $u_{t-1}$ are obtained from Engle and Granger (1987). We use the same procedure for other frequencies at $\pi, \pi / 2$ and $3 \pi / 2$.

For biannual $(\pi)$ frequency, the following equation is estimated:

$$
-\left(1-B+B^{2}-B^{3}\right) \text { employment }_{t}=C+\beta_{2}\left[-\left(1-B+B^{2}-B^{3}\right) y_{t}\right]+v_{t}
$$

Then, the auxiliary regression is specified as:

$$
v_{t}+v_{t-1}=\tau_{2}\left(-v_{t-1}\right)+\sum_{i=1}^{\rho} \Gamma_{i}\left(v_{t-i}+v_{t-1-i}\right)+\varepsilon_{2, t}
$$

In equation (9) we test the null of unit root by the coefficient $\tau_{2}$. The null hypothesis of no cointegration at frequencies $(\pi / 2),(3 \pi / 2)$ are tested by the cointegrating equation (10) and auxiliary regression (11).

$$
\begin{aligned}
& -\left(1-B^{2}\right) \text { employment } t=C+\beta_{3}\left[-\left(1-B^{2}\right) y_{t}\right]+\beta_{4}\left[-\left(1-B^{2}\right) y_{t}\right]_{t-1} w_{t} \\
& w_{t}+w_{t-2}=\tau_{3}\left(-w_{t-2}\right)+\tau_{4}\left(-w_{t-1}\right)+\sum_{i}^{\rho} \lambda_{i}\left(w_{t-i}+w_{t-2-i}\right)+\varepsilon_{3, t}
\end{aligned}
$$


We test the null of unit root in the residuals by using the joint F-statistics. If $\tau_{3} \neq \tau_{4}$, then we reject the conjugate pair of complex unit roots and claim that there is cointegration between the variables aggregate output and total employment.

\section{<Insert Table 2 here>}

Table 2 reports the test statistics for the cointegration tests at the $0, \pi, \pi / 2$ and $3 \pi / 2$ frequencies. Panel A reports the statistics for the aggregate output-total employment and Panel B reports the same for the aggregate output-nonagricultural employment. Note that the estimated parameters are from equations (6), (8) and (10) and the test statistics are from equations (7), (9) and (11). The former equations are insensitive to different lag orders but the latter equations are not. Therefore, Table 2 reports the similar estimates of the parameters but for different values of the test statistics. These results suggest that there is no statistically significant cointegration relationship between aggregate output and total employment at the $1 \%$ and $5 \%$ significance levels at all of the frequencies. Therefore, we fail to find a statistically significant long-run relationship between aggregate output and total employment. This is not parallel with what is reported for other countries such as for China (He, Zhang and Zhang, 2009), Greece (Milas, 2000) and Scotland (Bell, 1981). However we cannot reject the null of no-cointegration for aggregate output and non-agriculture employment at $\pi$ frequency at the 5\% significance level. Thus, we find a long-run relationship between aggregate output and non-agricultural employment. This is parallel to the existing theoretical and empirical studies such as Shepherd and Dixon (2008). As for the differences between agricultural and non-agricultural employment, Kuznets (1973) claims that the non-agricultural employment increases as the economy develops. This transformational change in the economy is documented by Chenery and Syrquin (1975). The structural change from agricultural intense to non-agricultural intense economy is also verified by other empirical papers. Ateşoğlu (1993) claims that the Kaldor's law that suggests a high correlation between living standards and the share of resources devoted to the industrial activity is valid for the U.S. economy. Chletsos and Kollias (1997) report a long-run relationship between the non-agricultural sector output and employment for Greece. Upender (2011) calculates the output elasticities of the employment for several sectors and finds support for the positive relationship between the non-agricultural sector output and employment. Similar results for Turkey are found by Berument et al. (2009), Aydıner-Avşar, and Onaran (2010), Akçoraoğlu (2010), and Tatoğlu (2011). Thus our results on the non-agricultural sector are mostly parallel to the existing literature. 


\section{IV.b. Sectoral Employment and Output}

As a next step, we investigate the relationship between aggregate output and sectoral employment levels in each of the nine main sectors of economic activity. This investigation is warranted because as the aggregate demand increases, the sectors may differ in terms of their employment generation. The sectoral employment generation may differ for the following reasons. First of all, the sectors may differ in terms of their labor intensity. For example, agriculture, mining and construction sectors are more labor intensive than electricity, transportation and finance. For this reason, as the aggregate demand increases, employment generation might be higher in these labor intensive sectors than in the other sectors. Second, the increase in aggregate demand might be due to external factors outside of the domestic economy. For a small open economy such as Turkey, shocks may come from the rest of the world and export oriented manufacturing sectors may experience output and employment increases. Third, even if each sector has the same labor intensity and aggregate demand shocks hit the sectors in a uniform fashion, the qualifications of labor in each sector might be different. For example, increasing employment in agriculture as a result of an increase in demand for labor will be easier than in the finance sector. This is because of the fact that hiring new people in agriculture is easier since it involves hiring relatively abundant unqualified workers. Historically, because of the structural change and the migration from rural to urban areas, the agricultural employment diminished persistently. However, during the global crisis of 2008-2009 the declining trend in the agricultural employment is reversed. Gürsel and İmamoğlu (2011) claim that this increase in the share of agricultural employment in Turkey is due to the increasing world agricultural prices and diminishing non-agricultural job opportunities due to the global crisis. Fourth, the labor market in some of the sectors might be non-competitive. For example, the labor demand of family owned businesses may not be sensitive to the economic fluctuations or shocks. If family owned businesses are concentrated in sectors such as agriculture or construction, then change in aggregate demand may not change the employment in these sectors. For these reasons we repeat the analysis for each sector of economic activity separately.

Table 3 reports the HEGY seasonal unit root tests for each sector. The test statistics for $t\left(\Lambda_{1}\right)$ suggest that we cannot reject the null hypothesis of unit root for Agriculture, Mining, Manufacturing, Construction, Wholesale trade, Transportation, Finance and Community Services. We can reject the null of unit root for Electricity when we have an Intercept $\{I\}$, and Intercept and Seasonal Dummies $\{I, S D\}$, but we cannot reject it when we have Intercept 
and Trend $\{I, T r\}$ and Intercept, Seasonal Dummies and Trend $\{I, S D$ and $\operatorname{Tr}\}$. Therefore, we can safely assume that all of the sectoral employment series that we consider are nonstationary. $^{8}$

\section{<insert Table 3 here>}

We next investigate the cointegration relationship for the disaggregated data. Table 4 reports the cointegration test results for the aggregate output and the different sectoral employment variables. We find cointegration relations in the following sectors: Mining $(\pi$, for four lags), Manufacturing (0, for six lags; $\pi / 2 \& 3 \pi / 2$, for four and six lags), Electricity, Gas and Water ( 0 , for eight lags; $\pi$, for four lags; $\pi / 2 \& 3 \pi / 2$, for four, six and eight lags), Wholesale and Retail Trade ( $\pi$, for four, six and eight lags), Transportation, Communication and Storage $(\pi / 2 \& 3 \pi / 2$, for six lags), Finance, Insurance, Real Estate and Business Services ( $\pi$, for four lags; $\pi / 2 \& 3 \pi / 2$, for four, six and eight lags), Community, Social and Personal Services $(0$, for six lags; $\pi / 2 \& 3 \pi / 2$, for four and six lags). Therefore, we may claim that when output increases, the employment in seven of the nine main sectors of economic activity also increase. The two sectors for which we could not find a long-run relationship between aggregate output and sectoral employment are agriculture and construction sectors. The differences in the responses of sectoral employment to the changes in output makes sense because economic shocks effect employment across different education background of the labor as well as across sectors differently (Berument et al., 2006 and Berument et al., 2009). Overall, Table 4 suggests a set of cointegration relationships between aggregate output and most of the sectoral employment. Thus, we can claim that there is a long run relationship between output and employment in seven of the nine sectors we considered at different frequencies. These results are mostly parallel with the existing literature that reports a longrun relationship between output and non-agricultural employment that we cited above. Asymmetric effect of output on employment is also well documented. For example, Basu and Foley (2011) consider the difference between service and non-service employments for the US. Palangkaraya and Yong (2011) consider various sectors across different productivity levels for Australia and He, Zhang and Zhang (2009) for China. Aydıner-Avşar and Onaran (2010) consider the effect income on employment for the high- and medium skilled sectors for Turkey. Thus, our results across the sectors are similar.

\footnotetext{
${ }^{8}$ For completeness, we also perform conventional unit root tests of ADF, PP and KPSS for the sectoral employment series. These tests are reported in Table A-2 of the Appendix. Some of the test statistics reveal contradictory results. However, overall we can claim that these series are at best difference stationary.
} 
<insert Table 4 here>

At this point, we would like to comment on a few characteristics of the agriculture and construction sectors. Although the share of the agricultural sector in the total employment is relatively large, its contribution to the total GDP is not significant. Table A-2 in the Appendix shows that the employment share of agriculture in the total was about 47 percent in 1988. It has declined substantially during the past 20 years. It was about 27 percent in 2007 . However, agriculture contributed only 10 percent to real GDP in 2007 which is down from 19 percent in 1988. Thus, agriculture is a declining sector both in terms of employment and in terms of its contribution to GDP. Employment in the agricultural sector in particular for women is in the form of unpaid family workers. Educational attainment of the labor force in agriculture is very low. About 84 percent of the labor force in agriculture has only primary schooling or less and 87 percent of the labor force is informally employed. Construction sector is a rather small sector both in terms of employment and its contribution to GDP. The share of construction sector in total employment did not change much over the past 20 years. It remained around six percent in 1988 and 2007. The relatively small contribution of this sector to real GDP was about seven percent in 1988 and declined to five percent in 2007. Work in the construction sector is labor intensive and seasonal. Human capital intensity is rather low where almost 60 percent of the employed has only primary schooling or less and 62 percent is informally employed.

The existence of the long-run relationship between aggregate output and employment in different sectors does not imply the existence of a short-run relationship. As we elaborated earlier, these two series may have a different dynamics in the long and the short-runs. Thus, next we assess if there is a short term relationship between aggregate output and the employment in the each of the different sectors. Following the methodology of Engle et al. (1993), we specify the following error correction model in equation (12):

$$
\begin{aligned}
& \left.\Delta_{4} \text { employment }=\sum_{j=1}^{q} \delta_{j} \Delta_{4} y_{t-j}+\sum_{i=1}^{q} \beta_{i} \Delta_{4} \text { employment }_{t-j}+\gamma_{11} \text { employment }_{1, t-1}-\alpha_{12} y_{1, t-1}-C\right) \\
& \left.+\gamma_{12} \text { employment }_{2, t-1}-\alpha_{22} y_{2, t-1}-C\right)-\left(\gamma_{13}+\gamma_{14} B\right)\left(\text { employment }_{3, t-2}-\alpha_{32} y_{3, t-2}\right. \\
& \left.-\alpha_{41} \text { employment }_{3, t-3}-\alpha_{42} y_{3, t-3}-C\right)+C+\varepsilon_{t}
\end{aligned}
$$

The estimated coefficients for the output differences $\left(\delta_{j}\right)$ are for the short-run relationship. Among the error correction terms, (employment $t_{1, t-1}-\alpha_{12} y_{1, t-1}-C$ ) is at 0 frequency, (employment ${ }_{2, t-1}-\alpha_{22} y_{2, t-1}-C$ ) is at $\pi$ frequency and (employment $_{3, t-2}-\alpha_{32} y_{3, t-2}-\alpha_{41}$ employment $_{3, t-3}-\alpha_{42} y_{3, t-3}-C$ ) is at the $\pi / 2$ and $3 \pi / 2$ 
frequencies. The estimates also include a constant term, seasonal dummies and the time trend. We include the error correction terms only if there is cointegration for a particular frequency. If there is no cointegration relationship at $0, \pi, \pi / 2$ and $3 \pi / 2$ frequencies, then none of the error correction terms are included. The estimates for the total employment, the nonagricultural employment and the sectoral employments are reported in Table 5. The table suggests that there is no statistically significant short-run relationship between output and employment in any one of the sectors except in the wholesale and retail trade sector. Not finding a short-run relationship is meaningful for the following reasons. First of all, the OECD's Employment Protection Index is the highest for Turkey out of the 40 countries that the study considers for the year 2008 (OECD, 2008). Thus, employment is not sensitive to output in the short-run for the most of the sectors. More importantly, in the error-correction specifications, the estimated coefficients of the error correction terms are negative and statistically significant. This implies that higher employment in one particular sector compared to its long run level lowers employment generation for the next period. Therefore, there is a long-run relationship between employment and output.

\section{<insert Table 5 here>}

Here a few words about the wholesale trade sector are in order. Table A-2 in the Appendix shows that this is one of the sectors that make a large contribution to real GDP. This contribution has increased from 20 percent in 1988 to 24 percent in 2007. However, there was a striking increase in the employment share of this sector from 11 percent in 1988 to 21 percent in 2007. This sector was the second largest employer in 2007 after agriculture. In this sector the workers are relatively well educated. The proportion of those with primary school education or less is about 40 percent. However the proportion of those with high school or more is about 39 percent. Nearly 42 percent of the employed are working informally. The economic activity in the wholesale sector i.e., (wholesale, retail trade and restaurants and hotels) includes tourism activities. This sector has a potential for generating employment since it is responsive to output changes both in the long-run and the short-run as our results indicate.

In order to assess how change in output level affects employment levels, we cannot employ parameter estimates from Equations 6-12. The reason for this is that the equations mentioned allow us to estimate the sum of the employment elasticity of the output across quarters rather than the conventional elasticity estimates. Therefore, we employ Engle and Granger (1987) type non-seasonal Cointegration/Error correction specifications. Estimates are reported in Table 6. Panel A reports the estimates of the coefficient of the output. Here, we 
did not report the estimated coefficients of the constant term, three seasonal dummies, a dummy variable for the post-2005 period and of the trend term in order to save space. The estimated coefficient for the total employment is 0.3231 and statistically significant at $1 \%$ level. This suggests that as output increases by $1 \%$, the employment increases by $0.3231 \%$. However, the increase in output by $1 \%$ increases the non-agricultural employment by a larger amount, by $0.5895 \%$. The remaining rows repeat the exercise for the disaggregated employment categories. These suggest that as output increases employment in agriculture and mining decrease. When the economy expands the traditional sectors get a lower share of employment from the total. Therefore in these traditional sectors, the employment creation ability weakens ${ }^{9}$. Lewis (1954) and Rostow (1960) among many others stress this economic transformation and transition process. Thus a larger response of the employment in the nonagricultures sector is parallel with the previous literature. More importantly, the estimated coefficient for non-agriculture sector is negative and statistically significant. This clearly suggests that higher output decreases agriculture employment and increases the other types of employments ${ }^{10}$.

\section{<insert Table 6 here>}

The largest increases in employment are observed in Electricity, Wholesale trade and Finance sectors. However, these are less than the increase in employment in the Construction sector. Panel B reports the estimates of the specification in the second stage. Here, we regress the employment growths on a constant, seasonal dummies, intercept dummy for the 2005:1, four lags of employment growth and four lags value of output growth and a lag value of the residual term obtained from the first stage regression. Panel B reports the sum of the estimated coefficients of output growth (Total Employment Effect) and the lag value of the residual term (Error Correction Term). The estimated coefficient for the total employment effect is not statistically significant for the aggregate employment, non-agriculture employment and all the sectoral employment levels except for the wholesale trade sector. Thus, we can claim that the estimates account for seasonality with seasonal dummies only. They do not suggest a short-run effect for the total employment. The estimates for short-run

\footnotetext{
${ }^{9}$ The agricultural employment may not be responsive to the changes in the total output. The prevalence of small family organizations in agriculture and of the unpaid family member type of employment may be the reasons for our not finding a relationship between total employment and total output. There is migration from agriculture to urban areas. Turkish economy as a developing country has undoubtedly undergone structural changes with a decline in agricultural employment and an increase in the services employment over the past two decades as seen in Table A-2. To control and distinguish between employment-output relationship on the one hand and structural economic change on the other, in the estimated relationships we also included a trend variable.

${ }^{10}$ We also observe a similar negative coefficient for the mining sector but due to this sector's small role in Turkish economy we did not elaborate on this issue further here.
} 
effects are parallel to seasonal cointegration tests in Table 5. The Error Correction Term is negative as expected for the total employment and employment for each sector.

Wilson (1960, p. 37) cites Hansen (1953, p. 68) for the positive short-run relationship between employment and output. Ireland and Smyth (1970) derive a short-run employment function and write the reverse of the traditional production function as employment as a function of output. They claim that the amount of capital to be acquired is a long-term decision but the change in amount of capital in the short-run is problematic. They find that the marginal unit of labor is more productive than the average unit of labor. However, Hart and Sharot (1978, p. 299) indicate that hours of work adjusts to output changes in the short-run but in the long-run men adjust to movements in output. They distinguish between men hours and the number of men in studying the output effects. In this study we measure employment with the number of men rather than with men hours due to data unavailability. It is possible to obtain a different result if men hours are used. Caporale and Skare (2011) for the 119 countries, find a positive effect of employment growth on output growth both in the short and the long-run using Granger causality. Pierluigi and Roma (2008) study the response of employment to output growth both in aggregate and sectoral levels for Germany, France, Italy, Spain and Netherlands by using the annual data of 1970-2006. For aggregate employment, they find a positive coefficient. For manufacturing, services and construction sectors they also observe a positive effect. Moreover, they estimate the short-run elasticities of total and sectoral employments to the output gap and find positive but small coefficients. According to their analysis employment follows a pro-cyclical pattern. In our analysis we did not find similar short-run effects. This may be due to the fact that either there is no short-run effect or the time span we consider is too short in order to detect this relationship. However, since we find such a relationship for the long-run but not for the short-run, then it is likely that there is no such short-run relationship. The results in Table 6 suggest that output increases, increase the aggregate employment and the non-agricultural employment but decreases the agriculture employment. This suggests that higher output increases migration from low productivity sectors such agriculture to non-agricultural sectors reducing agricultural employment as well as increases the non-agricultural employment.

Even if we cannot find a long-run relationship between total output and total employment but we do find a relationship between to total output and nonagricultural employment and a set of long-run relationships between total output and employment in different sectors. He, Zhang and Zhang (2009) find positive short and medium run multiplier effects of the demand shock (fiscal stimulus) on the employment for China using input-output 
tables. They also report corresponding different effects for different sectors. Milas (2000) finds a long-run relationship between output and employment for the Greek economy with Johansen cointegration method for tradable and non-tradable sectors. Even if they did not look at the short-run dynamics between output and employment, they report that the political decisions effect the employment. Bell (1981) explores the short and long-run effects of excess demand on the unemployment in Scotland using OLS and multiplier analysis. The long-run effects of excess demand are higher than those of the short-run. These results are all in line with our estimates.

\section{Caveats:}

In this study, we examine the relationship between total output on the one hand and various measures of employment on the other in Turkey. The various measures of employment include, total employment, non-agricultural employment and employment in the various sectors of economic activity. While examining the employment in various sectors of economic activity, we do not use the output or export volume corresponding of these various sectors. There are two reasons for this. First, the output data comparable to the employment data for each of the sectors of economic activity are not available. Second, our aim is to measure the effect of aggregate demand which is proxied by total output on employment. To this end, we note that it is the aggregate demand that is more likely to be influenced, controlled or monitored by the government policies rather than the sectoral outputs.

Another feature of our study is that we used the number of people employed as our measure of employment rather than man-hours worked. This is partly because the data on man-hours-worked by sectors of economic activity are not available and partly because the number of people employed or unemployed is more relevant to the social concerns such as social loss of unemployment ${ }^{11}$ and the social tensions that may arise as a result than manhours worked.

\section{Conclusion}

This paper investigates the long-run and the short-run relationships first, between aggregate output and total employment, next between aggregate output and non-agricultural employment and then between aggregate output and disaggregated employment by sectors of main economic activity. Quarterly data is used for the period 1988Q4 - 2008Q4. Recent time

\footnotetext{
${ }^{11}$ One can visit Cengiz and Şahin (2011) for the brief interpretation of unemployment as a measure of market inefficiency and its costs in terms of welfare losses.
} 
series techniques are employed in investigating the seasonal unit roots, cointegration properties and the error correction models. The main findings are as follows: We fail to find a long-run relationship between aggregate output and total employment however; we find it for the aggregate output and non-agricultural employment. We propose that aggregate demand may affect employment in a non-homogenous fashion across different sectors. Upon the investigation of the relationship between aggregate output and sectoral employments, we find statistically significant long-run relationships for seven of the nine sectors of economic activity that we considered. However, we find a significant short-run relationship only for the wholesale and retail trade sectors but not for the other eight main sectors. These findings are related to the various characteristics of the sectors of main economic activity. Further, these findings are consistent with the limited employment generating capacity of the Turkish industry and better employment generating capacity of the services sector in general. The negative coefficient for the agricultural employment elasticity of output suggests that higher output increases migration from sectors such as agriculture to non-agricultural sectors.

The finding of in general long-run but not short-run relationships has various implications. First of all, increasing employment need to be maintained with the sustainable income policies rather than the short-term stimulus measures. Second, employment generation may require a set of policies besides income policies to be implemented such as tax-breaks and social security premium assistances for the newly hired labor. In fact, the latter two policies have been implemented recently before the onset of global crisis as part of a program to fight unemployment. Third, government sponsored training programs for youth and woman may help to lower the firms' cost for newly hired labor and this might be arranged with the long-term perspectives of various sectors. Fourth, in order to help overall employment growth, targeted sectoral policies may be implemented. For instance, employment in the wholesale and the retail trade sector which includes tourism activities could increase employment both in the long-run and in the short-run in response to aggregate demand policies. In order to reduce unemployment and increase employment, cross-sector labor mobility could be improved by encouraging reallocation of workers from declining employment sectors to expanding employment sectors especially to help sectors exhibiting “jobless-growth" properties. Such policies may complement broad monetary and fiscal policies to increase the employment level. 


\section{References}

Akan, Y., Arslan, I., Karatay, P. and Druica, E. (2008). 'Effects of economic growth on employment in the knowledge society process (1980-2007)', Buletinul Universităţii Petrol, 3, pp. 23-30.

Akçoraoğlu, A. (2010). 'Employment, economic growth and labor market performance: The case of Turkey', Ekonomik Yaklasim, 21, pp. 101-114

Akerlof, G. A. and Shiller, R. J. (2009). Animal Spirits, How Human Psychology Drives the Economy, and Why It Matters for Global Capitalism. Princeton University Press, Princeton.

Ateşoğlu, H. S. (1993). 'Manufacturing and economic growth in the United States', Applied Economics, 25, pp. 67-69

Attfield, C. L. F. and Silverstone, B. (1998). 'Okun's law, cointegration and gap variables', Journal of Macroeconomics, 20, pp. 625-37.

Aydıner-Avşar, N. And Onaran, O. (2010). 'The determinants of employment: A sectoral analysis for Turkey', The Developing Economies, 48, pp. 203-31

Bailey, M. N. and Lawrence, R. Z. (2004). 'What happened to the great US job machine? The role of trade and electronic offshoring', Brookings Papers on Economic Activity, 35, pp. 211-284.

Baltagi, B. H., Baskaya, Y. S. and Hulagu, T. (2012). 'How different are the wage curves for formal and informal workers? Evidence from Turkey', Central Bank of the Republic of Turkey, Working Paper, 12, pp. 1-19.

Basu, D. And Foley, D. K. (2011). 'Dynamics of output and employment in the U.S. economy', University of Massachusetts Amherst Political Economy Research Institute, Working Paper, 248, pp. 1-37.

Bell, D. (1981). 'Regional output, employment and unemployment fluctuations', Oxford Economic Papers, 33, pp. 42-60.

Bent, H. (1991). The Political Economy of Poverty, Equity, and Growth in Egypt and Turkey, World Bank Comparative Study.

Berman, J. and Pfleeger, J. (1997). 'Which industries are sensitive to business cycles?', Monthly Labor Review, 120, pp. 19-25.

Bernanke, B. (2003). 'The jobless recovery', Global Economic and Investment Outlook Conference, Carnegie Mellon University, Pittsburgh, Pennsylvania, November 6.

Berument, H., Dogan, N. and Tansel, A. (2006). 'Economic performance and unemployment: Evidence from an emerging economy', International Journal of Manpower, 27, pp. 604-623.

Berument, H., Dogan, N. and Tansel, A. (2009). 'Macroeconomic policy and unemployment by economic activity: Evidence from Turkey', Emerging Markets, Finance and Trade, 45, pp. 21-34.

Bhalotra, S. R. (1998). 'The puzzle of jobless growth in Indian manufacturing', Oxford Bulletin of Economics and Statistics, 60, pp. 5-32.

Bhorat, H. and Hodge, J. (1999). 'Decomposing shifts in labour demand in South Africa', South African Journal of Economics, 67, pp. 348-380.

Blanchard, O. J. (1989). 'A traditional interpretation of macroeconomic fluctuations', American Economic Review, 79, pp. 1146-64.

Brechling, F. P. R. (1965). 'The relationship between output and employment in British manufacturing industries', The Review of Economic Studies, 32, pp. 187-216.

Caporale, G. M. and Skare, M. (2011). 'Short-and-long-run linkages between employment growth, inflation and output growth: Evidence from a large panel', Brunel University London Economics and Finance Working Paper Series, October, 11, pp. 1-29. 
Cengiz, S. and Şahin, A. (2011). 'Unemployment and welfare loss', (in Turkish), Ekonomi Bilimleri Dergisi, 3, pp. 135-144.

Chenery. H. B. and Syrquin, M. (1975). Patterns of Development, 1950-1970, Oxford University Press, London.

Chletsos, M. and Kollias, C. (1997). 'The effects of macroeconomic aggregates on employment levels in Greece: A causal analysis', Labour, 11, pp. 437-448.

Chow, G. C. and Lin, A. L. (1971). 'Best linear unbiased interpolation, distribution and extrapolation of time series by related series', Review of Economics and Statistics, 53, pp. 372-375.

Cuaresma, J. C. (2003). 'Okun's law revisited', Oxford Bulletin of Economics and Statistics, 65, pp. 439-452.

Dudu, H. and Çakmak, E. H. (2011). 'Regional impact of the climate change: A CGE analysis for Turkey', ERF Working Paper, 644, pp. 1-19.

Dasgupta, S. and Singh, A. (2005). 'Will service be the engine of Indian economic growth', Development and Change, 36, pp. 1035-1057.

Echevarria, C. (1997). 'Changes in sectoral composition associates with economic growth', International Economic Review, 38, pp. 431-52.

Engle, R. F. and Granger, C. W. J. (1987). 'Co-integration and error correction: Representation, estimation and testing', Econometrica, 55, pp. 251-76.

Engle, R. F. and Yoo, B. S. (1987). 'Forecasting and testing in co-integrated systems', Journal of Econometrics, 35, pp. 143-59.

Engle, R. F., Granger, C. W. J., Hylleberg, S. and Lee, H. S. (1993). 'Seasonal cointegration: The Japanese consumption function', Journal of Econometrics, 55, pp. 275-98.

Fox, L. and Sekkel, M. (2006). 'Job creation and quality of growth in Africa', Working Paper, The World Bank, 12, November.

Freeman, D. G. (2000). 'Regional tests of Okun's law', International Advances in Economic Research, 6, pp. 557-570.

Ghysels, E. and Perron, P. (1993). 'The effect of seasonal adjustment filters on tests for a unit root', Journal of Econometrics, 55, pp. 57-98

Goodman, W. G. (2001). 'Employment in services industries affected by recessions and expansions', Monthly Labor Review, 124, pp. 3-11.

Groshen, E. L. and Potter, S. (2003). 'Has structural change contributed to a jobless recovery?' Current Issues in Economics and Finance, 9, pp. 1-7.

Günçavdı, O., Küçükçiftçi, S. and McKay, A. (2004). 'Adjustment, stabilization and the analysis of the employment structure in Turkey: An input- output approach', Economics of Planning, 36, pp. 315-331.

Gürsel, S. and İmamoğlu, Z. (2011). 'Why is agricultural employment increasing in Turkey?', Betam Working Paper Series, 4, pp. 1-20.

Hamada, K. and Kurosaka, Y. (1984). 'The relationship between production and unemployment in Japan: Okun's law in comparative perspective', European Economic Review, 25, pp. 71-94.

Hamori S. and Tokihisa A. (2001). 'Seasonal cointegration and the money demand function: Some evidence from Japan', Applied Economics Letters, 8, pp. 305-310.

Hansen, Alvin (1953). A Guide to Keynes, McGraw- Hill, NewYork.

Hart, R. A. and Sharot, T. (1978). 'The short-run demand for workers and hours: A recursive model', The Review of Economic Studies, 45, pp. 299-309.

He, D., Zhang, Z. and Zhang, W. (2009). 'How large will be the effect of China's fiscal stimulus package on output and employment?', Pacific Economic Review, 14, pp. 730744. 
Holmes, M. J. and Silverstone, B. (2006). 'Okun's law, a symmetries and jobless recoveries in the United States: A markov - switching approach', Economics Letters, 92, pp. 293-99.

Hylleberg, S., Engle R. F., Granger, C. W. J. and Yoo, B. S. (1990). 'Seasonal integration and cointegration', Journal of Econometrics, 44, pp. 215-38.

Ireland, N. J. and Smyth, D. J. (1970). 'The specification of short-run employment models', The Review of Economic Studies, 37, pp. 281-285.

Kaufman, R. T. (1988). 'An international comparison of Okun's law', Journal of Comparative Economics, 12, pp. 182-203.

Khemraj, T., Madrick, J. and Semmler, W. (2006). 'Okun's law and jobless growth', Schwartz Center for Economic Policy Analysis, 3, pp. 1-10.

Kuznets (1973). 'Modern economic growth: Findings and reflections', Nobel Memorial Lecture, December, 1971, American Economic Review, 63, pp. 247-58.

Layard, R., Nickell, S. and Jackman, R. (1991). Unemployment: Macroeconomic Performance and the Labour Market, Oxford University Press, Oxford.

Lewis, W. A. (1954). 'Economic development with unlimited supplies of labour', Manchester School Econ.Soc. Stud, 22, pp. 19-191.

Lewis-Wren, S. (1986). 'An econometric model of U.K. manufacturing employment using survey data on expected output', Journal of Applied Econometrics, 1, pp. 297-316.

Madden, G. M. and Tuckwell, R. H. (1975). 'The output - employment relationship in Australian industry', Economic Record, September, 51, pp. 421-427.

Milas, C. K. (2000). 'Employment, output and political business cycle effects in the Greek non-tradable sector', Applied Economics, 32, pp. 123-133.

Moosa, I. A. (1997). 'A cross - country comparison of Okun's coefficient', Journal of Comparative Economics, 24, pp. 335-356.

Morrison, C. J. and Berndt, E. R. (1981). 'Short-run labor productivity in a dynamic model', Journal of Econometrics, 16, pp. 339-365.

Nabli, M. K., Jauregi, C. S. and Silva, S. J. (2007). 'Job creation in a high growth environment: The Mena region', Middle East and North Africa Working Paper Series, 49, The World Bank.

OECD (2008). Employment Protection Regulation and Labour Market Performance, OECD Employment Outlook.

Okun, A. (1962). 'Potential GNP: Its measurement and significance' in American Statisical Association, Proceedings of the Business and Economic Statistics Section, pp. 98104.

Okun, A. (1970). The Political Economy of Prosperity, New York: Norton.

Palangkaraya, A. and Yong, J. (2011). 'Trade liberalisation, exit, and output and employment adjustments of Australian manufacturing establishments', The World Economy, 34, pp. 1-22.

Pehkonen, J. (2000). 'Employment, unemployment and output growth in booms and recessions: Time series evidence from Finland, 1970-96', Applied Economics, 32, pp. 885-90.

Pierluigi, B. and Roma, M. (2008). 'Labour cost and employment across Euro area countries and sectors', European Central Bank Working Paper Series, 912, pp. 1-41.

Prachowny, M. F. J. (1993). 'Okun's law: Theoretical foundations and revised estimates', Review of Economics and Statistics, 75, pp. 331-36.

Price Waterhouse and Coopers (PWC) (2010). 'Doing Business in Turkey', PriceWaterHouseCoopers, October.

Rostow, W. W. (1960). The Stages of Economic Growth: A Non-Communist Manifesto, Cambridge University Press, United States of America. 
Sawtelle, B. (2007). 'Analyzing the link between real GDP and employment: An industry sector approach', Business Economics, 42, pp. 46-54

Shepherd, D. and Dixon, R. (2008). 'The cyclical dynamics and volatility of Australian output and employment', The Economic Record, 84, pp. 34-49.

Sögner, L. and Stiassny, A. (2002). 'An analysis of the structural stability of Okun's law: A cross - country study’, Applied Economics Letters, 14, pp. 1775-87.

Sögner, L. (2001). 'Okun's law: Does the Austrian unemployment-GDP relationship exhibit structural breaks', Empirical Economics, 26, pp. 553-64.

Smyth, D. J. (1986). 'The cyclical response of employment to output changes: United States manufacturing industries, 1948 to 1983', Applied Economics, 18, pp. 495-500.

Şahin, A. (2008). 'An investigation on the government intervention in wheat market in Turkey', Icfai University Journal of Public Finance, 6, pp. 72-78.

Şahin, A., Yılmaz, A. and Arslan, F. (2007). 'Wheat yield dynamics: A structural econometric approach', Pakistan Journal of Biological Sciences, 10, pp. 3533-3540.

Tarı, R. and Abası, T. (2010). 'Testing Okun's law using threshold cointegration and vector error correction model under the asymmetric effects: The case of Turkey', (in Turkish), Iktisat Isletme ve Finans, 25, pp. 53-77

Tatoğlu, F. Y. (2011). 'The long and short run effects between unemployment and economic growth in Europe', Dogus Universitesi Dergisi, 12 (1): 99-113

Telli, C., Voyvoda, E. and Yeldan, E. (2006). 'Modeling general equilibrium for socially responsible macroeconomics: Seeking for the alternatives to fight jobless growth in Turkey', METU Studies in Development, 33, pp. 255-293.

Tirkayi, A. and Özkan, H. N. (2011). 'Economic activity and unemployment dynamics in Turkey', Eskisehir Osmangazi Universitesi IIBF Dergisi, 6, pp. 173-184

Tregenna, F. (2008). 'Services to employment creation and growth in South Africa', South African Journal of Economics, 76, pp. 175-204.

Upender, M. (2011). 'Differential output elasticity of employment during posteconomic reform period in the Indian economy', The Singapore Economic Review, 56, pp. 189-202.

Verme, P. (2006). 'Constraints to growth and job creation in low-income commonwealth of independent States countries', World Bank Policy Research Working Paper, April, 3893.

Villaverde J. and Maza A. (2009). 'The robustness of Okun's law in Spain, 1980-2004 regional evidence', Journal of Policy Modeling, 31, pp. 289-297.

Wah, L. Y. (1997). 'Employment effects of output and technological progress in Malaysian manufacturing', Journal of Development Studies, 33, pp. 411-420.

Weber, C. E. (1997). 'The paper - bill spread and Blanchard's version of Okun's law", Applied Economics Letters, 4, pp. 437-440.

Wilson, G. W. (1960). 'The relationship between employment and output', The Review of Economics and Statistics, 42, pp. 37-43.

World Bank (2006). Turkey: Labor Market Study, Report No. 33254.

World Bank (2007). 'Job creation in an era of high growth', Middle East and North Africa Region, Economic Development and Prospects, The World Bank.

World Bank (2008). 'Hashemite Kingdom of Jordan resolving Jordan's labor market paradox of concurrent economic growth and high unemployment', World Bank Report, 39201.

Yeldan, E. (2010). 'Global crisis and Turkey: A macroeconomic assessment of the effects of fiscal stimulus measures on employment and labour markets': In: Crisis and Turkey: Impact Analysis of Crisis Response Measures, International Labour Organization Office, Ankara, Turkey, pp. 9-40. 
Table 1: HEGY Unit Root Test Results: Output and Employment

\begin{tabular}{|c|c|c|c|c|c|}
\hline Variables & C & Lags & $t\left(\Lambda_{1}\right)$ & $t\left(\Lambda_{2}\right)$ & $F\left(\Lambda_{3} \cap \Lambda_{4}\right)$ \\
\hline \multirow{12}{*}{ Output } & \multirow{3}{*}{$I$} & 4 & -0.911 & -1.635 & 1.883 \\
\hline & & 6 & -0.669 & -1.059 & 2.496 \\
\hline & & 8 & -1.118 & -0.790 & $3.743 *$ \\
\hline & \multirow{3}{*}{$I, S D$} & 4 & -0.903 & $-3.547 *$ & 0.364 \\
\hline & & 6 & -0.676 & -2.032 & 0.075 \\
\hline & & 8 & -1.071 & -1.804 & 0.141 \\
\hline & \multirow{3}{*}{$I, T r$} & 4 & -2.261 & -1.659 & 1.779 \\
\hline & & 6 & -3.093 & -1.082 & 2.795 \\
\hline & & 8 & -2.723 & -0.807 & $3.359 *$ \\
\hline & \multirow{3}{*}{$I, S D, T r$} & 4 & -2.307 & $-3.587 *$ & 0.446 \\
\hline & & 6 & -3.115 & -2.107 & 0.113 \\
\hline & & 8 & -2.686 & -1.862 & 0.205 \\
\hline \multirow{12}{*}{$\begin{array}{l}\text { Total } \\
\text { Employment }\end{array}$} & \multirow{3}{*}{$I$} & 4 & -1.958 & -1.764 & 0.505 \\
\hline & & 6 & -1.493 & -1.194 & 0.321 \\
\hline & & 8 & -1.266 & -0.814 & 0.204 \\
\hline & \multirow{3}{*}{$I, S D$} & 4 & -1.949 & -2.454 & 1.841 \\
\hline & & 6 & -1.450 & -1.812 & 1.438 \\
\hline & & 8 & -1.266 & -1.405 & 1.277 \\
\hline & \multirow{3}{*}{$I, T r$} & 4 & -1.212 & -1.793 & 0.529 \\
\hline & & 6 & -1.302 & -1.225 & 0.279 \\
\hline & & 8 & -0.931 & -0.834 & 0.213 \\
\hline & \multirow{3}{*}{$I, S D, T r$} & 4 & -1.266 & -2.482 & 1.859 \\
\hline & & 6 & -1.267 & -1.834 & 1.312 \\
\hline & & 8 & -0.922 & -1.415 & 1.271 \\
\hline \multirow{12}{*}{$\begin{array}{l}\text { Non-Agricultural } \\
\text { Employment }\end{array}$} & \multirow{3}{*}{$I$} & 4 & 0.934 & $-3.146^{* *}$ & 0.934 \\
\hline & & 6 & 0.400 & $-3.192 * *$ & 0.756 \\
\hline & & 8 & 0.901 & $-2.450^{*}$ & 0.516 \\
\hline & \multirow{3}{*}{$I, S D$} & 4 & 0.809 & $-3.330^{*}$ & 2.914 \\
\hline & & 6 & 0.405 & $-3.416^{*}$ & 2.489 \\
\hline & & 8 & 0.761 & -2.740 & 1.669 \\
\hline & \multirow{3}{*}{$I, T r$} & 4 & -1.332 & $-3.183^{* *}$ & 0.944 \\
\hline & & 6 & -1.754 & $-3.267 * *$ & 0.669 \\
\hline & & 8 & -1.071 & $-2.530 * *$ & 0.486 \\
\hline & \multirow{3}{*}{$I, S D, T r$} & 4 & -1.399 & $-3.376^{*}$ & 2.988 \\
\hline & & 6 & -1.703 & $-3.487 *$ & 2.278 \\
\hline & & 8 & -1.161 & $-2.829 *$ & 1.742 \\
\hline
\end{tabular}

Notes: I: Intercept, SD: Three seasonal dummies, Tr: Trend. $\Lambda_{1}, \Lambda_{2}, \Lambda_{3}$ and $\Lambda_{4}$ are explained in the text.

** The null hypothesis is rejected at a $1 \%$ significance level

* The null hypothesis is rejected at a 5\% significance level 
Table 2: Cointegration Test Results for Output and Employment Relationship

\begin{tabular}{|c|c|c|c|c|}
\hline & \multicolumn{4}{|c|}{ Panel A } \\
\hline & \multicolumn{4}{|c|}{ Four Lags } \\
\hline Frequencies & 0 & $\pi$ & \multicolumn{2}{|c|}{$(\pi / 2$ and $3 \pi / 2)$} \\
\hline Variables & $\beta_{1}$ & $\beta_{2}$ & $\beta_{3}$ & $\beta_{4}$ \\
\hline Total Employment & 0.3368 & 0.0789 & -0.3220 & 0.3421 \\
\hline Test statistics for cointegration & {$[-2.6594]$} & {$[-2.6219]$} & \multicolumn{2}{|c|}{ [4.4916] } \\
\hline & \multicolumn{4}{|c|}{ Six Lags } \\
\hline Total Employment & 0.3368 & 0.0789 & -0.3220 & 0.3421 \\
\hline Test statistics for cointegration & {$[-3.0303]$} & {$[-1.8875]$} & \multicolumn{2}{|c|}{ [3.6284] } \\
\hline & \multicolumn{4}{|c|}{ Eight Lags } \\
\hline Total Employment & 0.3368 & 0.0789 & -0.3220 & 0.3421 \\
\hline Test statistics for cointegration & {$[-2.6546]$} & {$[-1.5183]$} & \multicolumn{2}{|c|}{ [2.9453] } \\
\hline & \multicolumn{4}{|c|}{ Panel B } \\
\hline & \multicolumn{4}{|c|}{ Four Lags } \\
\hline Non-Agricultural Employment & 0.6250 & $0.0357 *$ & 0.5570 & 0.3527 \\
\hline Test statistics for cointegration & {$[-2.2407]$} & {$[-3.4521]$} & \multicolumn{2}{|c|}{ [4.7034] } \\
\hline & \multicolumn{4}{|c|}{ Six Lags } \\
\hline Non-Agricultural Employment & 0.6250 & $0.0357 *$ & 0.5570 & 0.3527 \\
\hline Test statistics for cointegration & {$[-2.3682]$} & {$[-3.5023]$} & \multicolumn{2}{|c|}{ [4.5538] } \\
\hline & \multicolumn{4}{|c|}{ Eight Lags } \\
\hline Non-Agricultural Employment & 0.6250 & 0.0357 & 0.5570 & 0.3527 \\
\hline Test statistics for cointegration & {$[-2.8158]$} & {$[-2.9257]$} & \multicolumn{2}{|c|}{ [3.8108] } \\
\hline
\end{tabular}

Notes: Test statistics are reported in brackets. Critical values are gathered from Engle and Granger (1987, Table III) and Engle et al. (1993, Table A.5)

** The null hypothesis is rejected at a $1 \%$ significance level

* The null hypothesis is rejected at a 5\% significance level 
Table 3: HEGY Unit Root Test Results: Output and Sectoral Employment

\begin{tabular}{|c|c|c|c|c|c|c|c|c|c|c|c|c|c|c|c|c|}
\hline Var. & $C$ & Lags & $t\left(\Lambda_{1}\right)$ & $t\left(\Lambda_{2}\right)$ & $F\left(\Lambda_{3} \cap \Lambda_{4}\right)$ & Var & $\mathrm{C}$ & $t\left(\Lambda_{1}\right)$ & $t\left(\Lambda_{2}\right)$ & $F\left(\Lambda_{3} \cap \Lambda_{4}\right)$ & Var. & $C$ & Lags & $t\left(\Lambda_{1}\right)$ & $t\left(\Lambda_{2}\right)$ & $F\left(\Lambda_{3} \cap \Lambda_{4}\right)$ \\
\hline \multirow{12}{*}{ 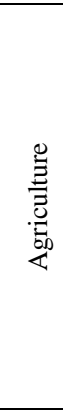 } & \multirow{3}{*}{$I$} & 4 & 0.761 & $-2.354 *$ & 0.629 & \multirow{12}{*}{ 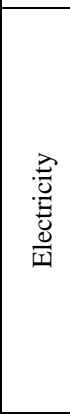 } & \multirow{3}{*}{ I } & -1.814 & $-2.636^{* *}$ & $14.629 * *$ & \multirow{12}{*}{ 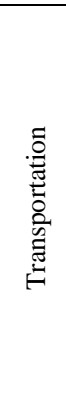 } & \multirow{3}{*}{$I$} & 4 & -1.115 & $-3.157 * *$ & $4.330 *$ \\
\hline & & 6 & 0.306 & $-2.271^{*}$ & 0.439 & & & $-3.833 * *$ & $-2.854 * *$ & $16.654 * *$ & & & 6 & -0.780 & $-2.891 * *$ & $3.973^{*}$ \\
\hline & & 8 & 0.699 & -1.452 & 0.496 & & & $-6.722 * *$ & $\begin{array}{l}-3.380 * * \\
\end{array}$ & $5.800 * *$ & & & 8 & -0.600 & $-2.506^{*}$ & 2.096 \\
\hline & \multirow{3}{*}{$I, S D$} & 4 & 0.630 & -2.882 & 2.211 & & \multirow{3}{*}{ I, SD } & -1.747 & -2.556 & $15.733^{* * *}$ & & \multirow{3}{*}{ I, $S D$} & 4 & -1.121 & $-3.101^{*}$ & 5.864 \\
\hline & & 6 & 0.269 & -2.857 & 1.867 & & & $-4.061 * *$ & -2.986 & $22.498 * *$ & & & 6 & -0.819 & -2.822 & 5.637 \\
\hline & & 8 & 0.578 & -2.020 & 1.607 & & & $-6.229 * *$ & $-3.134 *$ & $7.064 *$ & & & 8 & -0.650 & -2.448 & 2.957 \\
\hline & \multirow{3}{*}{$I, T r$} & 4 & -1.070 & $-2.347 *$ & 0.612 & & \multirow{3}{*}{$\mathrm{I}, \operatorname{Tr}$} & -1.842 & $\begin{array}{l}-638 * * \\
\end{array}$ & $14.449 * *$ & & \multirow{3}{*}{$I, T r$} & 4 & -2.918 & -3.316 *** & $5.072 * *$ \\
\hline & & 6 & -1.185 & $-2.271^{*}$ & 0.419 & & & -2.975 & $-2.832 * *$ & $16.360 * *$ & & & 6 & -2.897 & $-3.002 * *$ & $3.130^{*}$ \\
\hline & & 8 & -0.605 & -1.458 & 0.470 & & & -5.323 & $\begin{array}{l}3.336 * * \\
\end{array}$ & $5.632 * *$ & & & 8 & -2.390 & $-2.558^{*}$ & 2.301 \\
\hline & \multirow{3}{*}{$\begin{array}{c}\text { I, } S D, \\
\quad T R\end{array}$} & 4 & $\begin{array}{l}-1.147 \\
\end{array}$ & -2.889 & 2.190 & & \multirow{3}{*}{$\begin{array}{l}\text { I, SD, } \\
\text { Tr }\end{array}$} & -1.779 & -2.560 & $15.502 * *$ & & \multirow{3}{*}{$\begin{array}{l}\text { I, } S D \\
\quad T r\end{array}$} & 4 & -2.948 & $-3.267 *$ & $6.873^{*}$ \\
\hline & & 6 & $\begin{array}{l}-1.188 \\
\end{array}$ & -2.863 & 1.782 & & & -3.066 & $-2.957 *$ & $22.088 * *$ & & & 6 & -2.635 & -2.914 & 4.173 \\
\hline & & 8 & -0.684 & -2.035 & 1.600 & & & $-4.965 * *$ & $-3.089 *$ & $6.872^{*}$ & & & 8 & -2.416 & -2.500 & 3.352 \\
\hline \multirow{12}{*}{ 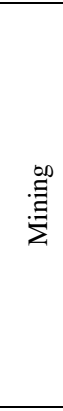 } & \multirow{3}{*}{$I$} & 4 & -1.611 & $-3.282 * *$ & $4.647 *$ & \multirow{12}{*}{ 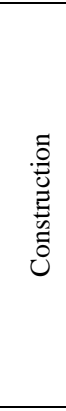 } & \multirow{3}{*}{ I } & -2.215 & -1.658 & 0.634 & & \multirow{3}{*}{$I$} & 4 & 1.096 & $-3.121 * *$ & $11.095^{* *}$ \\
\hline & & 6 & -1.862 & $-2.501 *$ & $6.524 * *$ & & & -2.873 & -1.168 & 0.211 & & & 6 & 1.573 & $-2.212 *$ & $9.726^{* * *}$ \\
\hline & & 8 & -1.212 & $-1.991 *$ & $6.689 * *$ & & & -2.307 & -0.808 & 0.075 & & & 8 & 1.490 & $-2.057^{*}$ & $5.990 * *$ \\
\hline & \multirow{3}{*}{$I, S D$} & 4 & -1.583 & $-3.199 *$ & 4.498 & & \multirow{3}{*}{ I, SD } & -2.245 & -2.371 & 2.175 & & & 4 & 1.088 & $-3.355^{*}$ & $10.734 * *$ \\
\hline & & 6 & -1.810 & -2.441 & 6.211 & & & -2.900 & -2.050 & 0.904 & & $I, S D$ & 6 & 1.572 & -2.608 & $9.615^{* *}$ \\
\hline & & 8 & -1.177 & -1.925 & 6.184 & & & -2.308 & -1.837 & 0.938 & $\breve{E}$ & & 8 & 1.453 & -2.345 & 5.721 \\
\hline & & 4 & -1.593 & $-3.305^{* *}$ & $4.745 * *$ & & & -2.148 & -1.648 & 0.627 & $\stackrel{\widetilde{a}}{=}$ & & 4 & -1.601 & $-3.202 * *$ & $11.012 * *$ \\
\hline & $I, T r$ & 6 & -0.780 & $-2.456^{*}$ & $6.492 * *$ & & $\mathrm{I}, \mathrm{Tr}$ & -2.805 & -1.161 & 0.209 & & $I, T r$ & 6 & -1.425 & $-2.286^{*}$ & $9.598 * *$ \\
\hline & & 8 & -0.739 & $-1.976^{*}$ & $6.518 * *$ & & & -2.256 & -0.801 & 0.074 & & & 8 & -1.249 & $-2.112 *$ & $6.012 * *$ \\
\hline & & 4 & -1.574 & $-3.220 *$ & 4.598 & & & -2.169 & -2.353 & 2.141 & & & 4 & -1.596 & $-3.441^{*}$ & $10.699^{* * *}$ \\
\hline & $I, S D, T r$ & 6 & $\begin{array}{l}-0.761 \\
\end{array}$ & -2.397 & 6.173 & & 1, SD, & -2.822 & -2.034 & 0.887 & & 1, SD, & 6 & -1.411 & -2.687 & $9.485 * *$ \\
\hline & & 8 & -0.716 & -1.909 & 6.014 & & & -2.249 & -1.820 & 0.920 & & & 8 & -1.246 & -2.402 & 5.803 \\
\hline & $I$ & 4 & -1.642 & $-2.105^{*}$ & $7.376^{* *}$ & & & -1.092 & $-3.119 * *$ & $4.376^{*}$ & & & 4 & -0.655 & -1.413 & $12.316^{* * *}$ \\
\hline & & 6 & -1.138 & -1.844 & $5.259^{* * *}$ & & I & -0.899 & $-2.835^{* *}$ & 3.024 & & I & 6 & -0.055 & -1.163 & $9.352 * *$ \\
\hline & & 8 & -1.112 & $-2.027 *$ & 2.856 & & & -1.137 & $-2.440^{*}$ & 2.312 & & & 8 & 0.406 & -0.963 & 1.693 \\
\hline & $I, S D$ & 4 & -1.573 & -1.960 & $12.407 * *$ & & & -1.021 & $-3.530 *$ & 4.292 & & & 4 & -0.668 & -1.900 & $13.538^{* * *}$ \\
\hline & & 6 & -1.157 & -1.873 & $9.577 * *$ & $\frac{0}{\sigma}$ & I, SD & -0.834 & $-3.492 *$ & 3.238 & $\stackrel{\lambda}{=}$ & I, SD & 6 & -0.041 & -1.602 & $11.103^{* * *}$ \\
\hline 苞 & & 8 & -1.098 & -1.898 & 5.140 & $\underline{\underline{v}}$ & & -1.053 & $-3.224 *$ & 2.212 & 声 & & 8 & 0.338 & -1.310 & 2.337 \\
\hline$\stackrel{\widetilde{J}}{\Xi}$ & $I, T r$ & 4 & -1.373 & $-2.147 *$ & $7.832 * *$ & $\bar{\Xi}$ & & -1.144 & $-3.153 * *$ & $4.534 *$ & हี & & 4 & $-4.014 *$ & -1.627 & $15.595 * *$ \\
\hline స్ & & 6 & -1.990 & -1.900 & $4.655^{* * *}$ & 3 & $\mathrm{I}, \mathrm{Tr}$ & $\begin{array}{l}-1.649 \\
\end{array}$ & $-2.882 * *$ & 2.628 & ō & $I, T r$ & 6 & $-3.865 *$ & -1.338 & $5.824^{* * *}$ \\
\hline & & 8 & -1.238 & $-2.047 *$ & $2.981^{*}$ & & & -1.308 & $-2.462 *$ & 2.352 & & & 8 & -2.156 & -1.004 & 2.129 \\
\hline & $I, S D, T r$ & 4 & -1.512 & -2.007 & $13.118^{* * *}$ & & & -1.189 & $-3.580^{*}$ & 4.449 & & & 4 & $-4.081 *$ & -2.124 & $17.373^{* *}$ \\
\hline & & 6 & $\begin{array}{l}-1.608 \\
\end{array}$ & -1.906 & $8.092 * *$ & & 1, SD, & -1.704 & $-3.568 *$ & 2.795 & & 1, SD, & 6 & $-3.669^{*}$ & -1.738 & $7.062^{*}$ \\
\hline & & 8 & -1.273 & -1.919 & 5.310 & & & -1.345 & $-3.266^{*}$ & 2.234 & & & 8 & -2.137 & -1.345 & 2.856 \\
\hline
\end{tabular}

Notes: I: Intercept, $S D$ : Three seasonal dummies, $\operatorname{Tr}$ : Trend. $\Lambda_{1}, \Lambda_{2}, \Lambda_{3}$ and $\Lambda_{4}$ are explained in the text.

** The null hypothesis is rejected at a $1 \%$ significance level

* The null hypothesis is rejected at a 5\% significance level 
Table 4: Cointegration Test Results for Output and Sectoral Employment Relationship

\begin{tabular}{|c|c|c|c|c|c|c|c|c|c|c|c|c|}
\hline \multirow{3}{*}{$\begin{array}{l}\text { Frequencies } \\
\text { Variables }\end{array}$} & \multicolumn{4}{|c|}{ Four Lags } & \multicolumn{4}{|c|}{ Six Lags } & \multicolumn{4}{|c|}{ Eight Lags } \\
\hline & \multirow{2}{*}{$\frac{0}{\beta_{1}}$} & \multirow{2}{*}{$\frac{\pi}{\beta_{2}}$} & \multicolumn{2}{|c|}{$(\pi / 2$ and $3 \pi / 2)$} & \multirow{2}{*}{$\frac{0}{\beta_{1}}$} & \multirow{2}{*}{$\frac{\pi}{\beta_{2}}$} & \multicolumn{2}{|c|}{$(\pi / 2$ and $3 \pi / 2)$} & \multirow{2}{*}{$\frac{0}{\beta_{1}}$} & \multirow{2}{*}{$\frac{\pi}{\beta_{2}}$} & \multicolumn{2}{|c|}{$(\pi / 2$ and $3 \pi / 2)$} \\
\hline & & & $\beta_{3}$ & $\beta_{4}$ & & & $\beta_{3}$ & $\beta_{4}$ & & & $\beta_{3}$ & $\beta_{4}$ \\
\hline \multirow{2}{*}{ Agriculture } & -0.2881 & 0.0384 & -0.8807 & 0.6881 & -0.2881 & 0.0384 & -0.8807 & 0.6881 & -0.2881 & 0.0384 & -0.8807 & 0.6881 \\
\hline & {$[-2.5957]$} & {$[-3.0105]$} & \multicolumn{2}{|c|}{ [3.6948] } & {$[-2.5748]$} & {$[-2.9855]$} & \multicolumn{2}{|c|}{ [3.8503] } & {$[-2.8146]$} & [-2.2393] & \multicolumn{2}{|c|}{ [3.6537] } \\
\hline \multirow{2}{*}{ Mining } & -1.3620 & $0.0972 *$ & -0.0337 & 0.5826 & -1.3620 & 0.0972 & -0.0337 & 0.5826 & -1.3620 & 0.0972 & -0.0337 & 0.5826 \\
\hline & {$[-2.2443]$} & {$[-3.3179]$} & \multicolumn{2}{|c|}{ [4.8328] } & {$[-2.5361]$} & {$[-2.6638]$} & \multicolumn{2}{|c|}{$[9.0034]$} & {$[-2.4007]$} & {$[-2.0116]$} & \multicolumn{2}{|c|}{ [6.9686] } \\
\hline \multirow{2}{*}{ Manufacturing } & 0.7422 & 0.0316 & -0.0781 & 0.2150 & $0.7422 *$ & 0.0316 & -0.0781 & 0.2150 & 0.7422 & 0.0316 & -0.0781 & 0.2150 \\
\hline & {$[-2.0072]$} & {$[-2.2299]$} & \multicolumn{2}{|c|}{$[18.1952]^{* *}$} & {$[-3.3431]$} & [-1.9186] & \multicolumn{2}{|c|}{$[15.4753]^{* *}$} & {$[-2.1646]$} & {$[-2.0466]$} & \multicolumn{2}{|c|}{ [8.6972] } \\
\hline \multirow{2}{*}{ Electricity } & 2.7281 & $1.0382 * *$ & 0.6698 & 0.3424 & 2.7281 & 1.0382 & 0.6698 & 0.3424 & $2.7281 *$ & $1.0382 * *$ & 0.6698 & 0.3424 \\
\hline & {$[-2.3836]$} & {$[-4.1267]$} & \multicolumn{2}{|c|}{$[26.9265]^{* *}$} & {$[-2.9267]$} & {$[-2.3799]$} & \multicolumn{2}{|c|}{$[24.0534]^{* *}$} & {$[-3.3546]$} & {$[-3.8185]$} & \multicolumn{2}{|c|}{$[16.5389]^{* *}$} \\
\hline \multirow{2}{*}{ Construction } & 0.2889 & 0.9378 & -0.8224 & 1.0949 & 0.2889 & 0.9378 & -0.8224 & 1.0949 & 0.2889 & 0.9378 & -0.8224 & 1.0949 \\
\hline & {$[-2.1927]$} & {$[-2.2737]$} & \multicolumn{2}{|c|}{ [5.6623] } & {$[-2.8100]$} & {$[-2.2208]$} & \multicolumn{2}{|c|}{ [2.9088] } & {$[-2.1223]$} & [-2.0779] & & \\
\hline & 1.3012 & $0.0591 * *$ & 0.0134 & 0.1992 & 1.3012 & $0.0591^{*}$ & 0.0134 & 0.1992 & 1.3012 & $0.0591 *$ & 0.0134 & 0.1992 \\
\hline priviesare & {$[-2.0680]$} & {$[-3.7949]$} & & & {$[-2.5484]$} & {$[-3.5943]$} & & & {$[-1.9960]$} & {$[-3.4992]$} & & \\
\hline Transnortation & 0.4433 & -0.1812 & -0.0811 & 0.1992 & 0.4433 & -0.1812 & -0.0811 & 0.1992 & 0.4433 & -0.1812 & -0.0811 & 0.1992 \\
\hline Hianspitationt & {$[-2.1574]$} & {$[-3.1087]$} & & & {$[-2.3833]$} & {$[-3.1385]$} & {$[10$} & & {$[-1.8640]$} & {$[-2.6200]$} & & \\
\hline & 1.1355 & $-0.1722^{*}$ & -0.0035 & 0.2818 & 1.1355 & -0.1722 & -0.0035 & 0.2818 & 1.1355 & -0.1722 & -0.0035 & 0.2818 \\
\hline T TIIfance & {$[-1.6700]$} & {$[-3.5854]$} & & & {$[-2.2084]$} & {$[-2.3372]$} & {$[14$.} & & {$[-1.9095]$} & {$[-2.4831]$} & & \\
\hline Community & 0.4792 & 0.2191 & 0.1289 & -0.0616 & $0.4792 *$ & 0.2191 & 0.1289 & -0.0616 & 0.4792 & 0.2191 & 0.1289 & -0.0616 \\
\hline 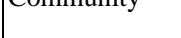 & {$[-3.0086]$} & {$[-2.3800]$} & & & {$[-3.4303]$} & [-1.6016] & {$[13$.} & & {$[-1.7529]$} & [-1.4996] & & \\
\hline
\end{tabular}

Notes: Test statistics are presented in brackets. Critical values are gathered from Engle and Granger (1987, Table III) and Engle et. al. (1993, Table A.5)

The test statistics for seasonal cointegration are reported in brackets.

The null hypothesis is rejected at a $1 \%$ significance level 
Table 5: Seasonal Error Correction Model Estimation Results

\begin{tabular}{|c|c|c|c|c|c|c|c|c|c|c|c|c|}
\hline & \multicolumn{4}{|c|}{ Four Lags } & \multicolumn{4}{|c|}{ Six Lags } & \multicolumn{4}{|c|}{ Eight Lags } \\
\hline Variables & $\sum_{j=1} \delta_{j}$ & $\gamma_{11}$ & $\gamma_{12}$ & $\left(\gamma_{13}+\gamma_{14} B\right)$ & $\sum_{j=1}^{T} \delta_{j}$ & $\gamma_{11}$ & $\gamma_{12}$ & $\left(\gamma_{13}+\gamma_{14} B\right)$ & $\sum_{j=1}^{q} \delta_{j}$ & $\gamma_{11}$ & $\gamma_{12}$ & $\left(\gamma_{13}+\gamma_{14} B\right)$ \\
\hline \multirow{2}{*}{ Employment } & 0.0146 & & & & -0.0141 & & & & 0.0772 & & & \\
\hline & {$[0.2880]$} & & & & {$[0.4981]$} & & & & $\begin{array}{l}{[0.7108]} \\
\end{array}$ & & & \\
\hline \multirow[b]{2}{*}{ Non-Agriculture } & 0.0182 & & $-0.6166^{* * *}$ & & 0.0988 & & $-0.7133^{* * *}$ & & 0.05712 & & $-0.5901 *$ & \\
\hline & {$[0.8160]$} & & {$[-2.9071]$} & & {$[0.9703]$} & & {$[-2.7911]$} & & {$[0.8681]$} & & {$[-1.8669]$} & \\
\hline \multirow{2}{*}{ Agriculture } & 0.0473 & & & & -0.1385 & & & & 0.0424 & & & \\
\hline & {$[0.4107]$} & & & & {$[0.7189]$} & & & & {$[0.7096]$} & & & \\
\hline \multirow{2}{*}{ Mining } & 0.6400 & & $-0.5522 * *$ & & 1.6417 & & & & 1.9337 & & & \\
\hline & {$[0.4054]$} & & {$[-2.9932]$} & & {$[1.2211]$} & & & & {$[1.2080]$} & & & \\
\hline \multirow{2}{*}{ Manufacturing } & 0.0661 & & & $-0.9275^{* *}$ & $\begin{array}{l}-0.1708 \\
\end{array}$ & $\begin{array}{l}-0.1538 \\
\end{array}$ & & $-1.0336^{* * *}$ & 0.1446 & & & \\
\hline & {$[1.0898]$} & & & {$[-4.7663]$} & {$[0.4898]$} & {$[1.3403]$} & & {$[-3.8109]$} & {$[0.9214]$} & & & \\
\hline \multirow{2}{*}{ Electricity } & -0.4708 & & $-0.6884 *$ & $-0.4766^{* * *}$ & -0.7735 & & & $-0.9666 * *$ & -0.2429 & $-0.0731^{* * *}$ & $-0.5891 * *$ & $-0.5706 * *$ \\
\hline & {$[0.4347]$} & & {$[-2.5316]$} & {$[-3.6777]$} & {$[0.3207]$} & & & {$[-5.6599]$} & {$[0.5382]$} & {$[-5.1344]$} & {$[-2.8110]$} & {$[-3.0289]$} \\
\hline \multirow{2}{*}{ Construction } & 0.6414 & & & & 0.7646 & & & & 0.9846 & & & \\
\hline & {$[1.9306]$} & & & & {$[1.7488]$} & & & & {$[1.6185]$} & & & \\
\hline \multirow{2}{*}{ Wholesale } & $-0.3987 * *$ & & $-0.6778^{* *}$ & & $-0.3030 * *$ & & $-0.6833^{*}$ & & $-0.3108 * *$ & & $-0.7154 *$ & \\
\hline & [4.6772] & & {$[-3.0758]$} & & {$[3.0260]$} & & {$[-2.4951]$} & & {$[2.8513]$} & & {$[-2.2073]$} & \\
\hline \multirow[b]{2}{*}{ Transportation } & -0.0020 & & & & 0.0135 & & & $-0.7455^{* * *}$ & -0.1355 & & & \\
\hline & {$[1.1705]$} & & & & {$[1.4801]$} & & & {$[-3.7778]$} & {$[1.3181]$} & & & \\
\hline \multirow{2}{*}{ Finance } & -0.1268 & & $-0.4754 * *$ & $-0.6476^{* * *}$ & -0.3575 & & & $-0.8767 * *$ & -0.1986 & & & $-0.8209^{* * *}$ \\
\hline & {$[0.9139]$} & & {$[-3.2214]$} & {$[-4.2482]$} & {$[0.7402]$} & & & {$[-4.3520]$} & {$[0.8742]$} & & & {$[-3.1693]$} \\
\hline \multirow{2}{*}{ Community } & -0.0975 & & & $-0.7858 * *$ & 0.1837 & $-0.3671^{*}$ & & $-0.6077^{* * *}$ & 0.2436 & & & \\
\hline & {$[0.3872]$} & & & {$[-4.6989]$} & {$[0.8290]$} & {$[-0.5181]$} & & {$[-3.8174]$} & {$[1.6079]$} & & & \\
\hline
\end{tabular}

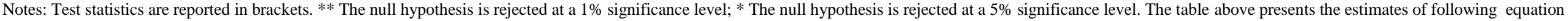

$\Delta_{4}$ employment $=\sum_{j=1}^{q} \delta_{j} \Delta_{4} y_{t-j}+\sum_{i=1}^{q} \beta_{i} \Delta_{4}$ employment $_{t-j}+\gamma_{11}\left(\right.$ employment $\left._{1, t-1}-\alpha_{12} y_{1, t-1}-C\right)+\gamma_{12}\left(\right.$ employment $\left._{2, t-1}-\alpha_{22} y_{2, t-1}-C\right)$

$-\left(\gamma_{13}+\gamma_{14} B\right)\left(\right.$ employment $_{3, t-2}-\alpha_{32} y_{3, t-2}-\alpha_{41}$ employment $\left._{3, t-3}-\alpha_{42} y_{3, t-3}-C\right)+C+\varepsilon_{t}$ 
Table 6: Estimation of Engle and Granger's Error Correction Model

\begin{tabular}{|l|c|c|c|}
\hline & Panel A & \multicolumn{2}{|c|}{ Panel B } \\
\hline Variables & $y_{t}$ & Total Employment Effect & $-0.4163^{* *}$ \\
\multirow{2}{*}{ Employment } & $0.3231^{* *}$ & -0.2419 & {$[-3.3419]$} \\
\hline \multirow{2}{*}{ Non-Agriculture } & {$[10.9965]$} & {$[-1.0559]$} & $-0.2358^{*}$ \\
\hline \multirow{2}{*}{ Agriculture } & $0.5895^{* *}$ & -0.2980 & {$[-2.0782]$} \\
& {$[16.3591]$} & {$[-0.7945]$} & $-0.4555^{* *}$ \\
\multirow{2}{*}{ Mining } & $-0.2664^{* *}$ & 0.1614 & {$[-3.0877]$} \\
& {$[-5.2497]$} & {$[0.3145]$} & $-0.3593 * *$ \\
\multirow{2}{*}{ Manufacturing } & $-1.3183^{* *}$ & 1.6738 & {$[-2.6625]$} \\
\hline \multirow{2}{*}{ Electricity } & {$[-10.1847]$} & {$[1.2612]$} & $-0.3446^{*}$ \\
\hline \multirow{2}{*}{ Construction } & $0.7108^{* *}$ & -0.4263 & {$[-2.4678]$} \\
& {$[18.5302]$} & {$[-1.1119]$} & -0.1139 \\
Wholesale & $2.5362^{* *}$ & -1.3637 & {$[-1.6962]$} \\
\hline \multirow{2}{*}{ Transportation } & {$[8.6788]$} & {$[-0.7836]$} & -0.0748 \\
\hline \multirow{2}{*}{ Finance } & $0.2281^{*}$ & 1.5865 & {$[-0.7782]$} \\
\hline \multirow{2}{*}{ Community } & {$[2.2007]$} & {$[1.8595]$} & -0.0649 \\
& $1.2643^{*}$ & $-0.7547 *$ & {$[-1.3192]$} \\
\hline
\end{tabular}




\section{Appendix}

Table A1. Data Definitions for the Employment by Branch of Economic Activity

\begin{tabular}{|l|l|}
\hline \multicolumn{1}{|c|}{ Variables } & \multicolumn{1}{c|}{ Definition } \\
\hline Employment & Total Employment \\
\hline Agriculture & Agriculture, Forestry, Hunting and Fishing \\
\hline Non-Agriculture & Employment - Agriculture \\
\hline Mining & Mining and Quarrying \\
\hline Manufacturing & Manufacturing \\
\hline Electricity & Electricity, Gas and Water \\
\hline Construction & Construction \\
\hline Wholesale & Wholesale and Retail Trade, Restaurants and Hotels \\
\hline Transportation & Transportation, communication and storage \\
\hline Finance & Finance, Insurance, Real Estate and Business Services \\
\hline Community & Community, Social and Personal Services \\
\hline
\end{tabular}

Note: We could seasonally adjust the series by using propositions such as X-11, X-12 or Tramo Seats. However, following comments of Ghysels and Perron (1993), we preferred seasonally unadjusted data in our analysis. They suggest using seasonal cointegration from seasonally unadjusted data. We prefer to analyze the long-run dynamics without losing information and by considering seasonality. The seasonally adjustment methods may affect the mean of the series

Table A-2. Sectoral Shares in Total Employment and Real GDP and Rates of Growth

\begin{tabular}{|l|r|r|r|r|r|r|r|r|}
\hline & $\begin{array}{c}\text { Share in Total } \\
\text { Employment }\end{array}$ & \multicolumn{2}{c|}{$\begin{array}{c}\text { Share in Real } \\
\text { GDP }\end{array}$} & \multicolumn{2}{c|}{$\begin{array}{c}\text { Rates of Growth in } \\
\text { Employment }\end{array}$} & \multicolumn{2}{c|}{$\begin{array}{c}\text { Rates of Growth } \\
\text { in Real GDP }\end{array}$} \\
\hline \multicolumn{1}{|c}{ Sectors } & 1988 & 2008 & 1988 & 2008 & $1988-2008$ & $2001-2008$ & $1988-2008$ & $2001-2008$ \\
\hline Agriculture & 46.4 & 26.8 & 18.9 & 11.0 & -1.7 & -3.2 & 0.2 & 0.9 \\
\hline Mining & 1.3 & 0.5 & 1.9 & 1.3 & -1.2 & 6.9 & 0.4 & 0.3 \\
\hline Manufacturing & 14.4 & 18.6 & 21.8 & 27.3 & 2.2 & 1.1 & 3.5 & 3.6 \\
\hline Electricity, Gas and Water & 0.2 & 0.5 & 2.2 & 3.7 & 7.1 & 0.6 & 5.5 & 6.9 \\
\hline Construction & 5.7 & 5.8 & 6.8 & 5.4 & 1.0 & -0.5 & 0.5 & 0.4 \\
\hline Wholesale & 11.4 & 21.0 & 20.2 & 25.5 & 3.7 & 1.8 & 3.6 & 3.8 \\
\hline Transportation & 4.4 & 5.3 & 11.5 & 13.7 & 1.8 & 0.6 & 3.2 & 4.0 \\
\hline Finance & 2.4 & 4.8 & 8.9 & 5.9 & 4.8 & 5.5 & 0.5 & 1.7 \\
\hline Community & 13.8 & 16.7 & 7.8 & 6.2 & 2.1 & 2.2 & 1.2 & 2.2 \\
\hline Total & 100.0 & 100.0 & 100.0 & 100.0 & 19.8 & 15.0 & 18.6 & 23.8 \\
\hline
\end{tabular}


Table A-3. Conventional Unit Root Test Results

\begin{tabular}{|l|c|c|c|c|c|c|}
\hline \multicolumn{1}{|c|}{ Variables } & \multicolumn{3}{|c|}{ with constant } & \multicolumn{3}{c|}{ with constant and trend } \\
\hline Output & ADF & PP & KPSS & ADF & PP & KPSS \\
\hline Total Employment & -0.4325 & $-4.4699^{* * *}$ & $1.2047 * * *$ & -2.4473 & -8.3793 & 0.1565 \\
\hline Agriculture & -1.6151 & $-3.8330^{* * *}$ & $1.1590^{* * *}$ & -2.4111 & $-6.3123^{* * *}$ & 0.2663 \\
\hline Mining & -0.3237 & $-3.8752^{* * *}$ & $0.9495^{* * *}$ & -1.9935 & $-5.5495^{* * *}$ & $0.2896^{* * *}$ \\
\hline Manufacturing & -1.9474 & $-2.6223^{*}$ & $0.8343^{* * *}$ & -1.9336 & $-3.4531^{* *}$ & $0.1891^{*}$ \\
\hline Electricity, Gas and Water & -1.1560 & -1.3714 & $1.2609^{* * *}$ & -6.5740 & $-6.5375^{* * *}$ & $0.1925^{*}$ \\
\hline Construction & -2.0299 & -2.0559 & $0.6510^{* *}$ & -1.9683 & -2.0297 & $0.2177^{* *}$ \\
\hline Wholesale & -2.3845 & $-5.2261^{* * *}$ & 0.2770 & -2.3792 & $-5.2980^{* * *}$ & $0.1587 * *$ \\
\hline Transportation & -1.0886 & -1.1991 & $1.1136^{* * *}$ & -3.0334 & -3.0334 & 0.1184 \\
\hline Finance & -1.1071 & -1.5250 & $1.2049 * * *$ & $-5.4016 * * *$ & $-5.3347 * * *$ & 0.0923 \\
\hline Community & -0.1416 & 0.7122 & $1.2253^{* * *}$ & -3.0925 & -2.8293 & $0.2661^{* * *}$ \\
\hline Critical Values: 1\% & -1.1979 & -1.1312 & $1.2443^{* * *}$ & $-5.9456 * * *$ & $-5.9155^{* * *}$ & 0.0566 \\
\hline Critical Values: 5\% & -3.5229 & -3.5133 & 0.7390 & -4.0753 & -4.0753 & 0.2160 \\
\hline Critical Values: $10 \%$ & -2.9018 & -2.8977 & 0.4630 & -3.4662 & -3.4662 & 0.1460 \\
\hline
\end{tabular}

*** The null hypothesis is rejected at a $1 \%$ significance level

** The null hypothesis is rejected at a 5\% significance level

* The null hypothesis is rejected at a $10 \%$ significance level 